\title{
Correlation between glycaemic control and lipid profile in type 2 diabetes mellitus patients
}

\author{
Rahul Y. Netragaonkar ${ }^{1}$, Amrut A. Swami ${ }^{2}$, Anand R. Bhide ${ }^{3}$
}

\begin{abstract}
${ }^{1}$ Associate Professor, ${ }^{2}$ Assistant Professor, Department of Community Medicine, DVVPF's Medical College Ahmednagar, Maharashtra. ${ }^{3}$ Assistant Professor, Department of Community Medicine, Rural Medical College, PIMS, Loni, Maharashtra.

Email: rahulnetra@gmail.com, draaswami@gmail.com, dranandrbhide@gmail.com
\end{abstract}

$\underline{\text { Abstract }}$

\begin{abstract}
Background: Patients with type 2 diabetes have increased prevalence of the dyslipidemia. A timely intervention to normalize these circulating lipids might reduce chances of the cardiovascular diseases. Glycated $\mathrm{Hb}(\mathrm{HbA} 1 \mathrm{c})$ is an indicator of glycemic status over long term. This study was conducted to find the association between glycemic control and lipid profile in patients with type $2 \mathrm{DM}$. In developing countries like India, fast industrialization and modern lifestyle is causing more number of DM patients daily. Type 2 diabetes mellitus is often associated with abnormalities of lipids which give rise to the increased incidence of micro vascular and macro vascular complications. We evaluated total 100 diabetic patients with type $2 \mathrm{DM}$ visiting our department in a tertiary care hospital and medical college. HbA1c levels were used for classification of patients into good $(<6.5)$ and poor $(\geq 6.5)$ glycaemic control and for comparing different lipid profile parameters in our study. There was significant association between the age and HbA1c levels $(p<0.05)$. There was significant association between the duration of diabetes and HbAlc levels $(\mathrm{p}<0.05)$. Mean HbAlc level in study population was $8.42 \pm 1.23$, showing overall poor glycaemic control in our study population, similarly the mean levels of lipids show a deranged pattern. Very strong correlation was seen between FBS levels and HbA1c $(p<0.0001)$. Positive correlation was seen between HbA1c levels and Total Cholesterol, LDL and VLDL while negative correlation was seen between HbA1c and HDL levels. The study concludes that to maintain good lipid profile and prevent further cardiovascular complications, better sugar control is required.
\end{abstract}

Key Words: Type 2 Diabetes Mellitus, Lipid Profile, Sugar Control, HbA1c

*Address for Correspondence:

Dr Amrut A. Swami, Assistant Professor, Department of Community Medicine, DVVPF's Medical College Ahmednagar, Maharashtra, INDIA.

Email: draaswami@gmail.com

Received Date: 02/06/2020 Revised Date: 07/07/2020 Accepted Date: 12/08/2020

DOI: https://doi.org/10.26611/10111611

This work is licensed under a Creative Commons Attribution-NonCommercial 4.0 International License. (oc)) BY-No

\begin{tabular}{|l|l|}
\hline \multicolumn{2}{|c|}{ Access this article online } \\
\hline Quick Response Code: & Website: \\
\hline
\end{tabular}

\section{INTRODUCTION}

Diabetes Mellitus is a group of common disorders that share the phenotype of hyperglycemia. ${ }^{1}$. India is also experiencing an endemic of Diabetes mellitus. In India dietary and lifestyle changes is causing more number of DM patients daily, which is estimated to reach 80 million by year $2030^{2}$. Diabetes mellitus is characterized by rise in blood sugar levels and subsequent lethal pathophysiological changes in the body. Diabetes is classified into two types, type 1 and type 2 . Type 2 diabetes is more prevalent and occurs either when the $\beta$-cells of pancreas do not produce enough insulin. Type 2 diabetes mellitus is often associated with abnormalities of lipids which give rise to the increased incidence of vascular complications ${ }^{3}$. $\mathrm{HbA} 1 \mathrm{c}$ is routinely used everywhere as a diagnostic tool for measuring long term glycemic control, it tells us about average blood sugar levels over the period of past few months. HbA1c also is a predictor of the risk for the complications in diabetes patients. Good glycemic control with the evidence of decreased level of the $\mathrm{HbAlc}$ is likely to reduce the risk of DM related complications ${ }^{4}$. For each $1 \%$ increase in $\mathrm{HbA} 1 \mathrm{c}$ value in DM patients, the estimated risk of Cardio Vascular Diseases (CVD) has been shown to be increased by almost $18 \%{ }^{5}$. Also in nondiabetic cases 
with $\mathrm{HbA1c}$ levels within the normal range, positive relationship has been demonstrated between $\mathrm{HbA} 1 \mathrm{c}$ and $\mathrm{CVD}^{6,7}$. Lipid profile abnormality present in type 2 diabetes mellitus patients is shown by abnormal high level of triglycerides (TG), low density lipoprotein (LDL-C), very Low density lipoprotein (VLDL-C) and the low levels of high density lipoprotein (HDL-C $)^{8-9}$. Altered lipid profile, especially high LDL-C, is very common in diabetes mellitus and it is strongly associated with poor glycemic control. Glycated haemoglobin (HbAlc) is the main tool for measuring long term glycemic control ${ }^{10}$. Many factors are responsible for diabetic dyslipedemia, these are: effect of insulin on liver Apoprotein productions, regulation of lipoprotein lipase (LpL), actions of cholesteryl ester transfer protein, and action of insulin on adipose and muscle tissues ${ }^{11,12}$. Dyslipidemia, especially high LDL-C, is common in diabetes mellitus and strongly associated with poor glycemic control. Glycated hemoglobin $(\mathrm{HbAlc})$ is main routinely used tool for measuring long term glycemic control ${ }^{13}$. $\mathrm{HbAlc}$ is a main indicator for mean blood glucose level; HbAlc predicts the risk of diabetic complications in diabetic patients. ${ }^{13}$

$\mathrm{HbA} 1 \mathrm{c}$ is the main indicator for mean blood glucose level; HbA1c predicts the risk of diabetic complications. ${ }^{14}$ This study was conducted to find the association between glycemic control and lipid profile in patients with type 2 DM.

\section{MATERIALS AND METHODS \\ RESULTS AND DISCUSSION}

We studied 100 cases of type $2 \mathrm{DM}$ visiting the Hospital. The cases were classified according to the glycemic control by $\mathrm{HbA} 1 \mathrm{C}$ levels using the cut off 6.5 with $\mathrm{HbA} 1 \mathrm{C}<6.5$ considered as good control while $\mathrm{HbA} 1 \mathrm{C} \geq 6.5$ as poor Glycaemic control. 16 out of total 100 patients $(16 \%)$ had good glycemic control $(\mathrm{HbA} 1 \mathrm{C}<6.5)$, while the rest 84 patients $(84 \%)$ had poor glycaemic control (HbA1C $\geq 6.5)$.

Table 1: Age categories and HbA1c levels

\begin{tabular}{cccc}
\hline Age & HbA1c $<6.5$ & HbA1c $\geq 6.5$ & Total N (\%) \\
\hline$<40 \mathrm{yr}$ & 6 & 8 & $14(14 \%)$ \\
$41-60 \mathrm{yr}$ & 9 & 43 & $52(52 \%)$ \\
$\geq 60 \mathrm{yr}$ & 1 & 33 & $34(34 \%)$ \\
\hline Total & 16 & 84 & $100(100 \%)$ \\
\hline \multicolumn{4}{c}{$\mathrm{X}^{2}=11.89 \mathrm{p}=0.0026$} \\
\hline
\end{tabular}

When we categorised patients according to the age groups of less than 40 years (14\%), 40 to 60 years (52\%) and more than 60 years (34\%), maximum number of patients $(52 \%)$ were from the age group of 40 to 60 years. There was significant association between age and HbA1c levels. $(p=0.0026)$

Table 2: Duration of Diabetes and Glycemic control

\begin{tabular}{cccc}
\hline Duration of Diabetes & HbA1c $<6.5$ & HbA1c $\geq 6.5$ & Total N (\%) \\
\hline$<10 \mathrm{yr}$ & 12 & 33 & $45(45 \%)$ \\
$\geq 10 \mathrm{yr}$ & 4 & 51 & $55(55 \%)$ \\
\hline Total & 16 & 84 & $100(100 \%)$ \\
\hline \multicolumn{5}{c}{$\mathrm{X}^{2}=6.926 \mathrm{p}=0.0085$} \\
\hline
\end{tabular}

Study Type: Cross Sectional Study

Study Population: All patients diagnosed with Type 2 Diabetes Mellitus, either visiting the OPD or admitted in Study Duration: Two years, January 2018 till December

study. investigated for the fasting blood glucose level, $\mathrm{HbA} 1 \mathrm{c}$ and Lipid Profile. Data was entered in Microsoft Excel and was analysed with Epi Info version 7.2.1. written informed consent before participating in the study. Inclusion Criteria:

- Patients of age $\geq 18$ years, both males and females

- Patients diagnosed as type 2 Diabetes Mellitus

- Patients with type-1 DM

- Hypothyroidism

- Patients already on lipid lowering drugs.

- Pregnant females with GDM

- Hypertensive patients using beta blockers or thiazide diuretics altered due to pathophysiologic conditions or drugs. 
Out of total 100 patients, $45 \%$ patients had diabetes for less than 10 years while rest of the $55 \%$ patients had the disease for more than 10 years. There was significant association between the duration of diabetes and HbAlc levels. $(p=0.0085)$

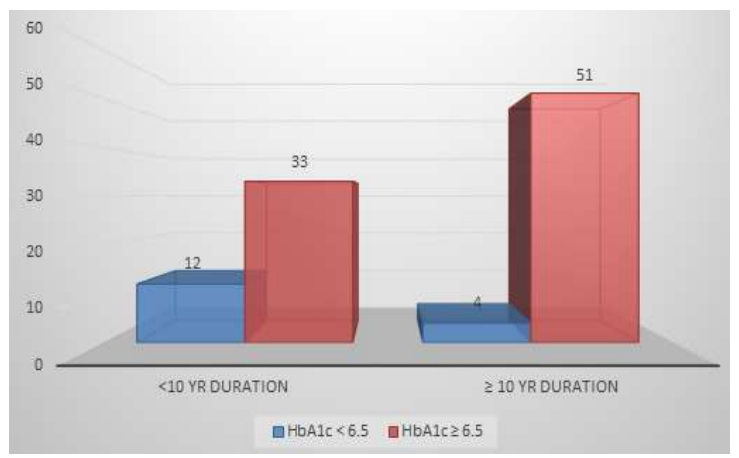

Figure 1: Duration of Diabetes and Sugar Control

The mean levels of the tests including HbA1C, Fasting Blood Glucose, Total Cholesterol, Triglycerides, LDL, VLDL and HDL are as follows-

Table 3: Mean and Standard Deviation values for different study parameters.

\begin{tabular}{ccc}
\hline Sr. No & Tests & Mean \pm Standard Deviation \\
\hline 1 & HbA1C $(\%)$ & $8.42 \pm 1.23$ \\
2 & FBS $(\mathrm{mg} / \mathrm{dl})$ & $184.42 \pm 57.0$ \\
3 & Total Cholesterol $(\mathrm{mg} / \mathrm{dl})$ & $164.13 \pm 43.25$ \\
4 & Triglycerides $(\mathrm{mg} / \mathrm{dl})$ & $156.63 \pm 94.23$ \\
5 & LDL $(\mathrm{mg} / \mathrm{dl})$ & $95.91 \pm 26.54$ \\
6 & VLDL $(\mathrm{mg} / \mathrm{dl})$ & $45.87 \pm 26.17$ \\
7 & HDL $(\mathrm{mg} / \mathrm{dl})$ & $46.52 \pm 19.50$ \\
\hline
\end{tabular}

The mean HbA1C levels in our study population was $8.42 \pm 1.23$, which shows the mean glycaemic control on a poor side. (HbA1C >6.5). The Mean FBS level observed in our study population was $184.42 \pm 57.0 \mathrm{mg} / \mathrm{dl}$. The means of total cholesterol levels in our study population was $164.13 \pm 43.25 \mathrm{mg} / \mathrm{dl}$, triglycerides level was $164.13 \pm 43.25 \mathrm{mg} / \mathrm{dl} \mathrm{while}$ the mean LDL, VLDL and HDL levels were $95.91 \pm 26.54 \mathrm{mg} / \mathrm{dl}, 45.87 \pm 26.17 \mathrm{mg} / \mathrm{dl}$ and $46.52 \pm 19.50 \mathrm{mg} / \mathrm{dl}$ respectively. The overall mean levels of lipid profile in the study population shows that the lipid profile is deranged with levels more than the expected normal values for our patients.

\begin{tabular}{ccccc}
\multicolumn{5}{c}{ Table 4: Comparison between different study parameters and HbA1C levels. } \\
\hline Sr. No & Parameter & HbA1C $<7$ & HbA1C $\geq 7$ & p value \\
& & $(\mathrm{n}=68)$ & $(\mathrm{n}=332)$ & \\
\hline 1 & $\mathrm{HbA1C}(\%)$ & $6.12 \pm 0.26$ & $8.65 \pm 1.29$ & $<0.0001$ \\
2 & FBS $(\mathrm{mg} / \mathrm{dl})$ & $154.27 \pm 56.16$ & $196.08 \pm 79.83$ & $<0.0001$ \\
3 & Total Cholesterol $(\mathrm{mg} / \mathrm{dl})$ & $162.78 \pm 42.49$ & $240.45 \pm 60.93$ & $<0.0001$ \\
4 & Triglycerides $(\mathrm{mg} / \mathrm{dl})$ & $153.48 \pm 72.49$ & $167.10 \pm 101.6$ & 0.63 \\
5 & LDL $(\mathrm{mg} / \mathrm{dl})$ & $79.52 \pm 43.64$ & $97.03 \pm 43.45$ & $<0.0001$ \\
6 & VLDL $(\mathrm{mg} / \mathrm{dl})$ & $33.42 \pm 13.87$ & $44.24 \pm 21.06$ & 0.0021 \\
7 & $\mathrm{HDL}(\mathrm{mg} / \mathrm{dl})$ & $53.20 \pm 12.7$ & $38.16 \pm 23.51$ & $<0.0001$ \\
\hline
\end{tabular}

As seen in table 4, significant correlation was observed in our study between different parameters and HbA1C levels. Very strong correlation was seen between FBS levels and HbA1C levels $(\mathrm{p}<0.0001)$. Indicating mean FBS levels on lower side in the patients with good Glycaemic control $(\mathrm{HbA} 1 \mathrm{C}<6.5)$. Significant positive correlation was observed between $\mathrm{HbA} 1 \mathrm{C}$ levels, total cholesterol $(\mathrm{p}=<0.0001)$ and LDL $(\mathrm{p}=<0.0001)$, VLDL $(\mathrm{p}=0.0021)$ and negative correlation with HDL $(\mathrm{p}=$ $0.001)$. There was no correlation between triglycerides levels.

\section{DISCUSSION}

Lipid abnormalities are very common in DM patients and they are frequently seen in patients with deranged blood sugars in type-2 diabetic mellitus. The abnormal lipid profile observed in type $2 \mathrm{DM}$ is said to be related to the insulin resistance as reported in many previous studies, which leads to the increased release of free fatty acids from fatty tissues, impaired muscle uptake of free fatty acids and an increased fatty acid release to the liver ${ }^{14}$ which has been closely associated with the diabetic dyslipedemia and 
hypertension ${ }^{15}$. Enormous risk to cardiovascular diseases is observed. Chronic hyperglycemia causes glycation of apolipoproteins and interferes with the normal pathways of lipoprotein metabolism ${ }^{16}$. We studied 100 cases of type 2 DM visiting the Hospital. The cases were classified according to the glycemic control by $\mathrm{HbA} 1 \mathrm{C}$ levels using the cut off 6.5 with $\mathrm{HbA1C}<6.5$ considered as good control while $\mathrm{HbA} 1 \mathrm{C} \geq 6.5$ as poor Glycaemic control. 16 out of total 100 patients $(16 \%)$ had good glycemic control $(\mathrm{HbA} 1 \mathrm{C}<6.5)$, while the rest 84 patients $(84 \%)$ had poor glycaemic control $(\mathrm{HbA} 1 \mathrm{C} \geq 6.5)$. Many recent studies have shown a similar percentage of patients $(14-19 \%)$ having poor glycemic control amongst diabetic patients. ${ }^{17-}$ ${ }^{20}$ When we categorised patients according to the age groups of less than 40 years (14\%), 40 to 60 years (52\%) and more than 60 years (34\%), maximum number of patients $(52 \%)$ were from the age group of 40 to 60 years. There was significant association between age and $\mathrm{HbAlc}$ levels. ( $\mathrm{p}=0.026$ ) In a similar study by . Ramona et al. [13], they found that as the age advances the glycemic control of the patients worsens, these findings are similar to our study. Out of total 100 patients, $45 \%$ patients had diabetes for less than 10 years while rest of the $55 \%$ patients had the disease for more than 10 years. There was significant association between the duration of diabetes and HbAlc levels. $(\mathrm{p}=0.0085) \mathrm{N}$ Vaish et al. ${ }^{16}$ observed patients having diabetes more than 10 years had mean $\mathrm{HbAlc}$ of $9.62 \pm 4.2$ compared to those having diabetes of less than 10 years with HbAlc of $6.42 \pm 2.1$. Their study suggested that patients with more duration of diabetes showed deranged sugar control as in our study. They recommended strict glycemic control to avoid cardiovascular complications. The overall mean levels of lipid profile in the study population shows that the lipid profile is deranged with levels more than the expected normal values for our patients. The mean $\mathrm{HbA1C}$ levels in our study population was $8.42 \pm 1.23$, which shows the mean glycaemic control on a poor side. (HbA1C >6.5). Many studies have reported the deranged lipid profile in patients of type $2 \mathrm{DM} .^{16-19}$ Very strong correlation was seen between FBS levels and HbA1C levels $(p<0.0001)$. Indicating mean FBS levels on lower side in the patients with good Glycaemic control $(\mathrm{HbA} 1 \mathrm{C}<6.5)$. Significant positive correlation was observed between $\mathrm{HbA1C}$ levels, total cholesterol $(\mathrm{p}=<0.0001)$ and LDL $(\mathrm{p}=<0.0001)$, VLDL $(p=0.0021)$ and negative correlation with HDL ( $p$ $=0.001)$. There was no correlation between triglycerides levels. A Begum et al. [18] reported similar findings with strong correlation between the sugar control and lipid profile parameters. They noted that there was a strong correlation between the FBS levels and HbA1C levels $(\mathrm{p}<0.05)$, lipid parameters and HbA1c levels $(\mathrm{p}<0.05)$. IM
Artha et al. [19] and P Satyanarayana [20] also showed similar findings.

\section{CONCLUSION}

Significant association between the age, duration of diabetes and sugar control in the form of $\mathrm{HbAlc}$ levels was seen in our study results. A positive correlation between the HbAlc and dyslipidaemia was seen in our study results. Similar positive correlation of $\mathrm{HbAlc}$ level was also seen in previous studies ${ }^{11}$. HbAlc showed positive correlations with LDL and VLDL and negative correlations was found between HbA1c and HDL levels. Very strong positive correlation was seen between FBS levels and $\mathrm{HbA} 1 \mathrm{C}$ levels in our study population. Thus our study concludes that good sugar control is necessary in diabetic patients to maintain good lipid profile and avoiding any further atherogenic complications from dyslipidaemia.

\section{REFERENCES}

1. Singh G, Kumar A. Relationship among HbA1c and lipid profile in Punajbi type 2 diabetic population. Journal of Exercise Science and Physiotherapy. 2011 Dec;7(2):99.

2. Meenu J, Jadeja Jayendrasinh M, Neeta M. Correlation between $\mathrm{HbA} 1 \mathrm{c}$ values and lipid profile in type 2 diabetes mellitus. TC (mg/dl). 2014;147:35-40.

3. Sharma S, Agrawal RP, Choudhary M, Jain S, Goyal S, Agarwal V. Beneficial effect of chromium supplementation on glucose, $\mathrm{HbA} 1 \mathrm{C}$ and lipid variables in individuals with newly onset type-2 diabetes. Journal of Trace Elements in Medicine and Biology. $2011 \mathrm{Jul}$ 1;25(3):149-53.

4. Assamang G, Schute H. The prospective Cardiovascular Minister (procam) study; Prevalence of hyperlipidemia in persons with hypertension and/or diabetes mellitus and the relationship to coronary heart disease. American Heart Journal 1988; 116:1713.

5. Selvin E, Marinopoulos S, Berkenblit G, Rami T, Brancati FL, Powe NR, et al.. Meta-analysis: glycosy-lated hemoglobin and cardiovascular disease in diabe-tes mellitus. Ann Intern Med 2004; 14: 421-431.

6. Erciyas $\mathrm{F}$ et al.. Glycemic control, oxidative stress and lipid profile in children with type 1 Diabetes Mellitus. Arch. Med. Res. 2004; 35:134-140

7. Rahimi HR, Mohammadpour AH, Dastani M, Jaafari MR, Abnous K, Mobarhan MG, Oskuee RK. The effect of nano-curcumin on $\mathrm{HbAlc}$, fasting blood glucose, and lipid profile in diabetic subjects: a randomized clinical trial. Avicenna journal of phytomedicine. 2016 Sep;6(5):567.

8. Irene M Stratton, Amanda I Alder et al.., Association of glycemia with macrovascular and microvascular complications of type 2 diabetes (UKPDS 35); Brit Med J. 2000 Vol $321: 405-416$

9. Khaw KT, Wareham N, Bingham S, Luben R, Welch A and Day N. Association of hemoglobin A1c with cardiovascular disease and mortality in adults: the Euro-pean Prospective Investigation into Cancer in Norfolk. Ann Intern Med 2004; 141: 413-420. 
10. Deeg R, Ziegenhorn J. Kinetic enzymatic method for automated determination of total cholesterol in serum. Clin Chem 1983; 29: 1798-802.

11. Mooradian AD, Haas MJ, Wehmeier KR, Wong NC. Obesity related changes in high density lipoprotein metabolism. Obesity (Silver Spring). 2008; 16:1152-1160.

12. Mooradian AD, Haas MJ, Wong NC. Transcriptional control of apolipoprotein A-1 gene expression in diabetes. Diabetes.2004; 53:513-520.

13. Gligor Ramona et al.. Relationship between glycosylated hemoglobin and lipid metabolism in patients with type 2 diabetes. 2011; 21(2): pp. 313-318.

14. Goldberg IJ. Clinical review 124: Diabetic dyslipidemia: causes and consequences. J Clin Endocrinol Metab.2001; 86:956-971.

15. Ginsberg HN. REVIEW: Efficacy and mechanisms of action of statins in the treatment of diabetes dyslipidemia. J Clin Endocrinol Metab. 2006; 91:383-392.

16. Vaish N, Chilloriya P. TO STUDY THE LIPID PROFILE AND HBA1C STATUS IN TYPE2 DM OBESE AND NON OBESE. International Journal of Medical and Biomedical Studies. 2019 Sep 23;3(9).

17. Alzahrani SH, Baig M, Aashi MM, Al-shaibi FK, Alqarni DA, Bakhamees WH. Association between glycated hemoglobin $(\mathrm{HbAlc})$ and the lipid profile in patients with type 2 diabetes mellitus at a tertiary care hospital: a retrospective study. Diabetes, metabolic syndrome and obesity: targets and therapy. 2019;12:1639.

18. Begum A, Irfan SR, Hoque MR, Habib SH, Parvin S, Malek R, Akhter S, Sattar S, Sarkar S. Relationship between HbA1c and Lipid Profile Seen in Bangladeshi Type 2 Diabetes Mellitus Patients Attending BIRDEM Hospital: A Cross-Sectional Study. Mymensingh medical journal: MMJ. 2019 Jan;28(1):91-5.

19. Artha IM, Bhargah A, Dharmawan NK, Pande UW, Triyana KA, Mahariski PA, Yuwono J, Bhargah V, Prabawa IP, Manuaba IB, Rina IK. High level of individual lipid profile and lipid ratio as a predictive marker of poor glycemic control in type-2 diabetes mellitus. Vascular Health and Risk Management. 2019;15:149.

20. Satyanarayana P, Agrahari P. EVALUATION OF GLYCATED HEMOGLOBIN AS A PROGNOSTIC MARKER OF DYSLIPIDEMIA IN DIABETES MELLITUS TYPE 2 IN NORTH INDIAN POPULATION. International Journal of Scientific Research. 2019 Nov 30;8(11).

\section{Source of Support: None Declared Conflict of Interest: None Declared}

Policy for Articles with Open Access:

Authors who publish with MedPulse International Journal of Community Medicine, Print ISSN: 2579-0862, Online ISSN: 2636-4743 agree to the following terms: Authors retain copyright and grant the journal right of first publication with the work simultaneously licensed under a Creative Commons Attribution License that allows others to share the work with an acknowledgement of the work's authorship and initial publication in this journal.

Authors are permitted and encouraged to post links to their work online (e.g., in institutional repositories or on their website) prior to and during the submission process, as it can lead to productive exchanges, as well as earlier and greater citation of published work. 